\title{
Productivity and Profitability of Two Varieties of Ampalaya (Momordica charantia L.) under Different Nutrient Solutions and their Combination in an Aggregate Hydroponics System
}

Reyna Mae C. Caintic ${ }^{1 \star}$ and Rosario A. Salas ${ }^{2}$

\section{ABSTRACT}

Hydroponics is a system of growing plants in nutrient solutions which could be from organic or inorganic sources with or without the use of aggregate medium. It is an alternative way of growing vegetables that would overcome problems encountered in conventional farming like soil acidity, alkalinity, and soil-borne diseases. This study was conducted to evaluate the growth, yield, and profitability of ampalaya varieties grown under aggregate hydroponic systems using different nutrient solutions. The experiment was laid out in a Factorial Randomized Complete Block Design with three replications using ampalaya hybrids as factor $A$ and nutrient solutions as factor B. The two ampalaya hybrids (Galaxy and Jade Star) applied with commercial solution showed significantly greater values in terms of horticultural parameters, yield, and yield components. Between the two ampalaya hybrids, no significant effect was observed in most of the characteristics except on the weight of roots. Galaxy had heavier roots compared to Jade Star. Consistent superiority of plants applied with commercial solution was manifested in most parameters. The overall results revealed that production of ampalaya hybrid using an aggregate hydroponic system is profitable.

Keywords: aggregate hydroponics, ampalaya, nutrient solutions, postharvest qualities

\section{INTRODUCTION}

Ampalaya (Momordica charantia L.) or bitter gourd belongs to the family Cucurbitaceae or Gourd family. It is also known as paria (llocano, Indonesia), palia (Bisaya), peria (Malaysia), and Balsam pear (English). It is high in vitamins and an excellent source of iron, calcium, and antioxidants (Salas et al 2013). Aside from its nutritional value, ampalaya has been a

\footnotetext{
${ }^{1,2}$ Visayas State University, Department of Horticulture, Visca, Baybay City, Leyte, Philippines 


\section{Productivity and Profitability of Two Varieties of Ampalaya}

folkloric cure for generations but has now been proven to be an effective herbal medicine for many ailments, with the Philippine variety as the most potent. It contains a mixture of flavanoids and alkaloids which make the pancreas produce more insulin to regulate blood sugar in diabetics. It has many other herbal benefits being an antioxidant, paraciticide, antibacterial, and antipyretic (Department of Agriculture 2017).

One of the major problems in ampalaya production is the incidence of soil-borne diseases particularly bacterial wilt. Control of the disease has been conducted primarily by cultural practices such as crop rotation, soil tillage, proper crop management, and seed treatment. While these practices could not effectively prevent infection of $R$. solanacearum to the plant, efforts have been sought to help farmers keep their plants away from bacterial wilt. With agricultural development nowadays, several technologies were developed to address this problem, one of which is through hydroponic system. With hydroponics, high productivity for vegetable culture provides an alternative method to the growers who are facing soil-related problems such as nematode infestation, diseases, energy shortage, limited expansion of arable land, and nutrient imbalances (Kratky \& Bowen 1988). Therefore, the susceptibility of vegetables to weeds, pests, and diseases are minimized or absent when they are grown hydroponically (Banez \& Manipon 2000).

Recently, there is a growing demand for safer and high quality food using low cost cultivation and production systems. The incorporation of organic fertilizer is also indispensable to sustain agriculture. It also has many advantages. Compared to chemical fertilizer, it consists of organic components, it is cheaper and environment-friendly. Different composted organic wastes are also recommended as nutrient sources for plants grown in substrates. Organic nutrient sources have been proven to be successful in some vegetables such as melon, cucumber, lettuce, and basil production in soilless culture (Gul et al 2007, El-Shinawy et al 1999; Succop 1998). Hence, this study was conducted to evaluate the growth, yield, and profitability of ampalaya varieties grown under aggregate hydroponic system using different nutrient solutions.

\section{MATERIALS AND METHODS}

\section{Seedling production}

A mixture of river sand and carbonized rice hull of 1:1 ratio by volume was prepared. The river sand was screened to remove stones and other debris of undecomposed materials. The mixture was heated and sterilized over fire to eliminate harmful microorganisms that can cause diseases, and was allowed to cool off after sterilization before placing it in a cellular tray for seed germination. Sowing rate was done at one seed per seedling per 
cell of the tray. Watering was done daily. One week after germination, the seedlings were hardened by exposing them gradually to the sun and reducing water supply until the seedlings experienced temporary wilting. This process was done to minimize transplanting shock. A good seedling should be in the four or five leaf stage, healthy, vigorous, and stocky.

\section{Transplanting of Seedlings}

The hardened seedlings were transplanted into individual pots $(6 \times 10 \mathrm{~cm})$ for aggregate hydroponic system. Each treatment had three replications. The seedlings were transplanted 2 weeks after emergence. Transplanting of seedlings was done late in the afternoon to minimize transplanting shock. Care was observed when removing the seedlings from the cellular tray in order to keep the soil intact.

\section{Aggregate Preparation and the Hydroponic System}

The river sand, one source of the aggregates, was purchased from a quarrying company in Albuera, Leyte. The river sand was rinsed thoroughly with running tap water to remove adhering dirt and was sun dried after. Meanwhile, the purchased coco coir dust from Abuyog, Leyte was submerged for 3-5 days in a drum filled with water. This process was done to remove the outer fibers of the coconut since coco coir dust has excellent cation exchange ability and tends to hold things like salt which, when used in hydroponic system, could damage the plants. Then, the water was squeezed out from the coco coir which was sun dried for a day. The river sand and coco coir were mixed at a ratio of 1:1 volume with 1 pail of clean river sand to one pail of dried coco coir.

\section{Preparation of Commercial Nutrient Solution}

Fifty liters of commercial nutrient solution was obtained from the Department of Horticulture, College of Agriculture and Food Science, Visayas State University, Visca, Baybay City, Leyte. The solution was placed in a plastic drum as treatment 1 and reserved for the experiment. Chemical analysis [First Analytical Services and Technical Cooperative (F.A.S.T) Laboratories in Cebu City] of the commercial nutrient solution and the ferments is shown in Table 1.

\section{Preparation of Fermented Plant Juice}

Fresh shoot leaves of malunggay (Moringa oleifera Lam.) harvested early in the morning were chopped finely, and were placed in a pail. Musa sp. (Cardava) peels were taken from a VSU market vendor and were washed 


\section{Productivity and Profitability of Two Varieties of Ampalaya}

and chopped. Twenty kilograms of Kuhol (Pomacea canaliculata) was cooked until its flesh can be easily removed from the shell. These were finely chopped and placed in the pail, then mixed with molasses and water at a ratio of $1: 1: 1$ by volume. The resulting mixture was placed in a plastic pail (52 $\mathrm{cm}$ in height and $47 \mathrm{~cm}$ in diameter), until it was 75 percent full, covered with craft paper, placed in a cool, dry place and fermented for a month or until white molds appeared or a sweet/sour, alcoholic odor was observed. The ferments were strained using an ordinary plastic strainer with a $0.425-\mathrm{mm}$ mesh. The filtrate was placed in a container and then stored in a cool and dry place until used at a ratio of $500 \mathrm{~mL}$ fermented extracts per 16 liters of water.

Table 1.Chemical analysis of banana peel, malunggay leaf and kuhol ferments and commercial inorganic nutrient solution

\begin{tabular}{lcrrr}
\hline Chemical Analysis & $\begin{array}{c}\text { Commercial } \\
\text { Solutions }\end{array}$ & Malunggay & Kuhol & Banana peel \\
\hline Total Nitrogen $(\mathrm{ppm} \mathrm{N})$ & 182.00 & 1110.00 & 500.00 & 2.00 \\
Total Phosphorus $(\mathrm{ppm} \mathrm{P})$ & 54.55 & 80.00 & 1448.00 & 9.00 \\
Total Potassium $(\mathrm{ppm} \mathrm{K})$ & 203.60 & 1360.00 & 515.00 & 1.00 \\
Total Calcium $(\mathrm{ppm} \mathrm{Ca})$ & 174.15 & 520.00 & 3843.00 & 2.00 \\
Total Magnesium $(\mathrm{ppm} \mathrm{Mg})$ & 40.28 & 1440.00 & 613.00 & 839.00 \\
Total Sulfur $(\mathrm{ppm} \mathrm{S})$ & 66.30 & 320.00 & 2.00 & 4.00 \\
\hline \hline
\end{tabular}

\section{Experimental Design and Statistical Analysis}

A 2 × 8 experiment in Factorial Randomized Complete Block Design was used in this study with ampalaya hybrids as factor $A$ and nutrient solutions as factor B. All treatments were replicated three times with 5 sample plants per replication. The treatments were the following:

Factor A-Ampalaya Hybrid

$\mathrm{T}_{1}$ - Galaxy

$\mathrm{T}_{2}$-Jade star

Factor B - Nutrient Solution

$\mathrm{T}_{1}$ - Commercial nutrient solution

$\mathrm{T}_{2}$ - Fermented malunggay

$\mathrm{T}_{3}$ - Fermented banana peel

$\mathrm{T}_{4}$ - Fermented kuhol

$T_{5}-T_{1}$ Commercial nutrient solution $+T_{2}$ Fermented malunggay (1:1 ratio)

$T_{6}-T_{1}$ Commercial nutrient solution $+T_{3}$ Fermented banana peel (1:1 ratio)

$T_{7}-T_{1}$ Commercial nutrient solution $+T_{4}$ Fermented kuhol (1:1 ratio)

$T_{8}-T_{2}$ Fermented malunggay $+T_{3}$ Fermented banana peel $+T_{4}$ Fermented Kuhol (1:1:1 ratio) 


\section{Fertilizer Application}

Fermented malunggay, kuhol and banana peel, and their combination were used as fertilizer/nutrient solution. A hundred to hundred fifty $\mathrm{mL}$ of the different designated fertilizers were poured immediately to the base of the plants early every morning and late in the afternoon until the last harvest.

\section{Trellising, Training, and Pruning of Vines}

Trellising net with a height of $2.5 \mathrm{~m}$ was established 1 week after transplanting. This served as the trellis to support the growth and development of amplaya plants. Vertical trellises (along the row) on individual plants were done to facilitate data gathering and overhead nylon trellises were strained on vertical trellises to redirect vine growth at early vegetative stage. All female flowers and lateral branches below the overhead trellis were removed by pruning. Vine training ended at fruit setting.

\section{Data Gathering Procedure}

\section{Horticultural Characteristics}

The vine length $(\mathrm{cm})$ was determined by measuring the length of 5 randomly selected sample plants per treatment from the ground level up to the tip of the terminal end of the leaf of the main stem. The number of days from germination to female flowering was determined by recording the number of days from seed germination up to the time when $85 \%$ of the plants had produced female flowers. The number of days to maturity was determined by counting the number of days from transplanting to the first harvest. The number of lateral vines was determined by counting the number of lateral vines that developed from the five (5) sample plants per replicate at harvest. The total number of lateral vines was divided by the number of sample plants per treatment plot to get the average. The root length $(\mathrm{cm})$ per plant was obtained by measuring the length of roots of sample plants from the base to the apex of the longest root after the last harvest of the fruits. Total length was divided by the number of sample plants per treatment to get the average. The root fresh weight per plant was determined by cutting the adjoining base between roots and stem of sample plants per treatment plot after the last harvest of the fruits. The roots, including root hairs, were cleaned and weighed to determine the fresh weight. The fresh herbage weight $(\mathrm{g})$ per plant was weighed immediately and was divided by the total number of sample plants per treatment to get the average. Percent survival was determined by counting the number of plants that survived until 
Productivity and Profitability of Two Varieties of Ampalaya

maturity using the formula:

Percent survival $=\frac{\text { No. of plants that survived }}{\text { No. of plants planted }} \times 100$

Yield and Yield Components

The fruit size $(\mathrm{cm})$ was obtained by measuring the broadest part of the circumference and length of the fruit that developed from sample plants per treatment plot using a tape measure. The fruit circumference was divided by 3.14 to get the fruit diameter. The number and weight $(\mathrm{kg})$ of marketable fruit/plant was determined by counting and weighing the total marketable fruits that were fully developed and free from damage either from insect or disease. The number and weight $(\mathrm{kg})$ of non-marketable fruit/plot was determined by counting and weighing the fruits that do not meet the criteria of marketability. The total fruit yield was determined by adding the yield of marketable and non-marketable fruits per plot.

\section{Cost and Return Analysis}

The production cost was determined by recording all the expenses incurred throughout the conduct of the study from land preparation up to harvesting. This included expenses for chemicals, fertilizers, seeds, other materials, and labor cost incurred in the field operations. The gross income was determined by multiplying the yield of each treatment plot by the current price of ampalaya per kilogram. The net income was determined by subtracting the total expenses of every treatment from the gross income.

\section{RESULTS AND DISCUSSION}

\section{Horticultural Characteristics}

Table 2 shows the horticultural characteristics of ampalaya hybrids grown in different nutrient solutions under aggregate hydroponic system. There was no significant difference in the growth performance of the two ampalaya hybrids in terms of female flower production, early maturity, vine length, weight of roots, percent survival, and fresh herbage yield. On the other hand, significant differences were observed in the number of lateral vines and length of roots between hybrids. Jade Star produced more vines (17.54) and had shorter roots $(47.35 \mathrm{~cm})$ than Galaxy hybrid.

Root length and percent survival were not significantly affected by the 
different nutrient solutions. However, the production of early female flower and maturity were significantly affected by the different nutrient solutions. Ampalaya grown in commercial nutrient solution significantly produced female flowers early (33 days) and matured early (42 days), producing the most marketable fruits that consequently gave the significantly highest yield. Moreover, ampalaya applied with commercial nutrient solution significantly exhibited the most number of vines, heaviest weight of roots, and fresh herbage yield, though those applied with ferments in combination with commercial inorganic nutrient solution also produced comparable yields. This indicates that the formulation of organic nutrient solution with commercial inorganic solution is a feasible approach to reduce the cost and, at the same time, attain the desired optimum yield. This strategy would be very instrumental in reducing carbon emissions into the atmosphere, thereby helping mitigate the effects of climate change.

Longer vines mean that there are more lateral branches to bear more fruits. In hydroponics, plants obtain nutrients and water from the substrates by uptake through their roots (Rao \& Cramer 2003). Taiz and Zieger (1998) revealed that shoot size is equated with root size which is also dependent on the capacity of roots to uptake nutrients and rates of photosynthesis. The development of the root system affects the ability of the plants to absorb nutrients, which was manifested by the comparable length of vines, weight of roots, $100 \%$ percent survival, and fresh herbage yield of plants applied with commercial nutrient solution and its combination with organic ferments. The low herbage yield of plants applied with organic ferments alone might be attributed to the strong adsorption of organic nutrients on the hydroponic aggregates making them less available for plant uptake (Taiz \& Zieger 1998). Plants applied with fermented banana peel $\left(T_{3}\right)$ manifested inferior horticultural characteristics. This is because banana peel ferment had small amounts of nutrients necessary for the growth and development of ampalaya (Table 2). Nevertheless, no significant interaction was found between the different nutrient solutions and the two ampalaya hybrids on the growth performance of the plant under aggregate hydroponic system. 
Productivity and Profitability of Two Varieties of Ampalaya

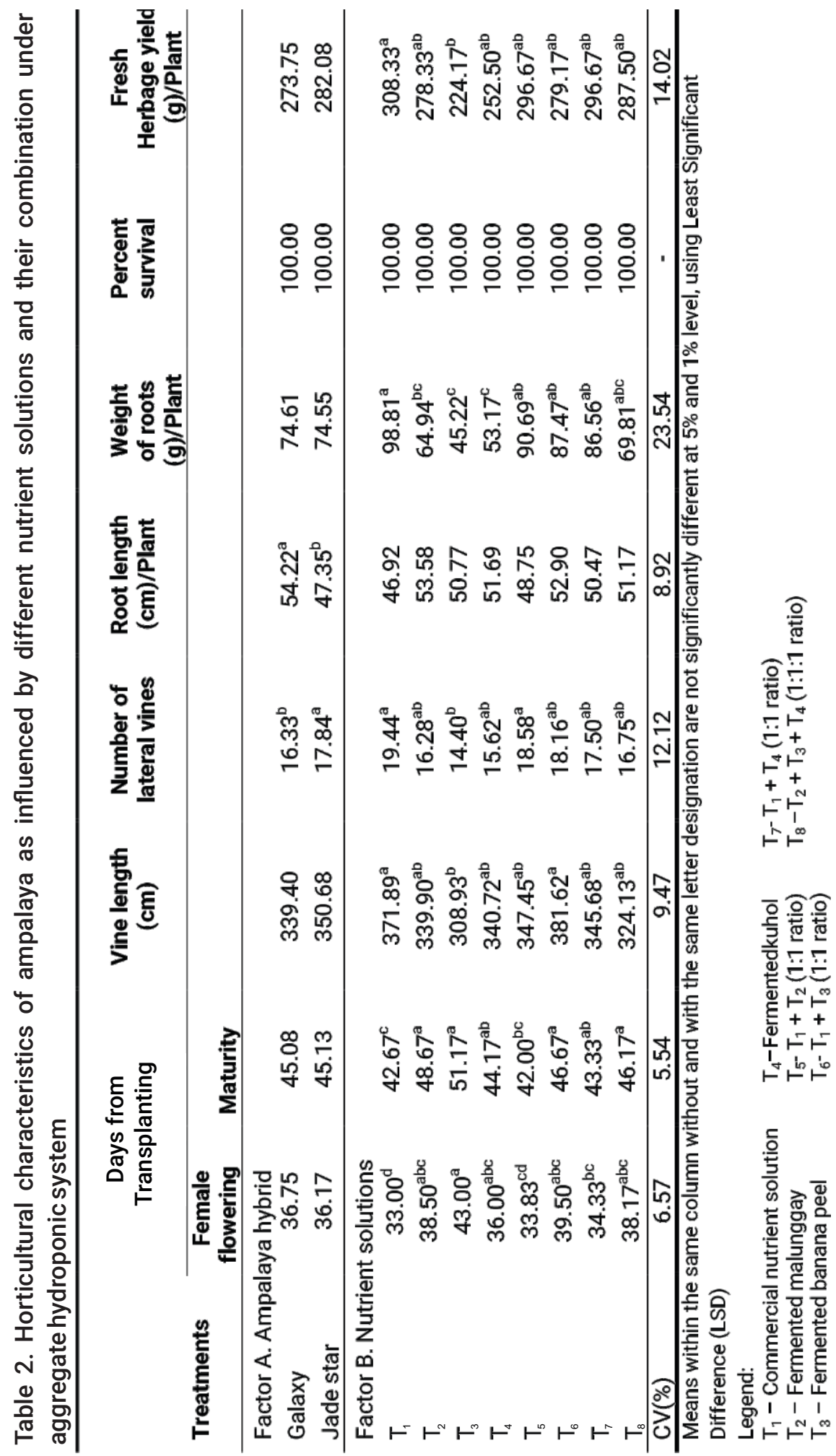




\section{Yield and Yield Components of Ampalaya}

Table 3 shows the yield and yield components of ampalaya grown in different nutrient solutions under aggregate hydroponic system. Yield performance of the two ampalaya hybrids did not differ significantly, but was affected by the different nutrient solutions in terms of number and weight of marketable fruits and fruit yield (tons/ha). Ampalaya plants applied with commercial nutrient solution $\left(T_{1}\right)$ obtained the highest number (1.43) and weight $(0.58 \mathrm{~kg})$ of non-marketable fruits per plant, while the lowest was obtained with the application of fermented kuhol $\left(T_{4}\right)$. These non-marketable fruits were smaller, damaged, and some were infested with fruit fly that affected their growth, development, and appearance. In terms of marketable fruits, ampalaya plants applied with commercial nutrient solution significantly obtained the highest number (12.33) and weight of marketable fruits per plant $(2.79 \mathrm{~kg})$ and total fruit yield $(22.98$ tons $/ \mathrm{ha})$, followed by those applied with organic ferments in combination with commercial solution. This could be correlated with the longer and higher number of vines produced in ampalaya applied with commercial nutrient solutions, which could probably be due to the readily available nutrients such as nitrogen, phosphorus, potassium, calcium, magnesium, sulfur, iron, manganese, copper, and zinc in the solution (Salas \& Salas 2014). Notably, the application of fermented banana peel significantly obtained the lowest yield and yield components.

Table 4 shows the interaction effects between the different nutrient solutions and ampalaya hybrids on the length of fruits and weight of nonmarketable fruits. Fruit length of the two ampalaya hybrids applied with $T_{1}$ Commercial solution, $T_{2}$ - fermented malunggay $\left(T_{2}\right), T_{5}-T_{1}+T_{2}\left(1: 1\right.$ ratio), $T_{6}-$ $\mathrm{T}_{1}+\mathrm{T}_{3}$ (1:1 ratio) and $\mathrm{T}_{8}-\mathrm{T}_{2}+\mathrm{T}_{3}+\mathrm{T}_{4}$ (1:1:1 ratio) were just comparable; however, when applied with $T_{3}$ - fermented banana peel, $T_{4}$ - fermented kuhol, and $T_{7}-T_{1}+T_{4}$ (1:1 ratio), Galaxy produced longer fruits compared to Jade Star. According to the description of the East West Seed Company, Galaxy hybrid has large, glossy, dark green fruits that are uniformly cylindrical with blunt blossom end while Jade Star is a hybrid bitter gourd with medium size fruits (https://ph.eastwestseed.com/). 
Productivity and Profitability of Two Varieties of Ampalaya

Table 3. Yield and yield components of ampalaya as influenced by different nutrient solutions and their combination under aggregate hydroponic system

\begin{tabular}{lccccc}
\hline \multirow{2}{*}{ Treatments } & \multicolumn{2}{c}{ Marketable } & \multicolumn{2}{c}{ Non-marketable } & \multirow{2}{*}{$\begin{array}{c}\text { Total Fruit } \\
\text { yield }\end{array}$} \\
\cline { 2 - 5 } & $\begin{array}{c}\text { Number } \\
\text { Fruits/plant }\end{array}$ & $\begin{array}{c}\text { Weight (kg) } \\
\text { Fruits/plant }\end{array}$ & $\begin{array}{c}\text { Number } \\
\text { Fruits/plant }\end{array}$ & $\begin{array}{c}\text { Weight (kg) } \\
\text { Fruits/plant }\end{array}$ & (tons/ha) \\
\hline Factor A. Ampalaya hybrid & & & & & \\
Galaxy & 9.13 & 1.56 & 0.97 & 0.38 & 12.92 \\
Jade star & 8.24 & 1.54 & 1.23 & 0.48 & 13.61 \\
\hline Factor B. Nutrient solutions & & & & \\
$\mathrm{T}_{1}$ & $12.33^{\mathrm{a}}$ & $2.79^{\mathrm{a}}$ & 1.43 & 0.58 & $22.89^{\mathrm{a}}$ \\
$\mathrm{T}_{2}$ & $7.50^{\mathrm{c}}$ & $0.88^{\mathrm{de}}$ & 1.00 & 0.34 & $8.14^{\mathrm{cd}}$ \\
$\mathrm{T}_{3}$ & $3.17^{\mathrm{d}}$ & $0.56^{\mathrm{d}}$ & 1.03 & 0.31 & $5.68^{\mathrm{d}}$ \\
$\mathrm{T}_{4}$ & $7.83^{\mathrm{bc}}$ & $1.32^{\mathrm{c}}$ & 0.97 & 0.43 & $10.72^{\mathrm{c}}$ \\
$\mathrm{T}_{5}$ & $10.17^{\mathrm{ab}}$ & $2.00^{\mathrm{b}}$ & 1.07 & 0.46 & $16.40^{\mathrm{b}}$ \\
$\mathrm{T}_{6}$ & $10.33^{\mathrm{abc}}$ & $1.92^{\mathrm{b}}$ & 1.10 & 0.47 & $15.98^{\mathrm{b}}$ \\
$\mathrm{T}_{7}$ & $9.83^{\mathrm{abc}}$ & $2.13^{\mathrm{b}}$ & 1.13 & 0.52 & $17.68^{\mathrm{b}}$ \\
$\mathrm{T}_{8}$ & $7.83^{\mathrm{bc}}$ & $0.84^{\mathrm{cd}}$ & 1,07 & 0.31 & $7.67^{\mathrm{cd}}$ \\
\hline $\mathrm{CV}(\%)$ & 16.33 & 16.28 & 25.46 & 17.59 & 16.93 \\
\hline
\end{tabular}

Means within the same column without and with the same letter designation are not significantly different at $5 \%$ and $1 \%$ level, using Least Significant Difference (LSD)
Legend: $\mathrm{T}_{1}$-Commercial nutrient solution
$\mathrm{T}_{5}-\mathrm{T}_{1}+\mathrm{T}_{2}(1: 1$ ratio $)$
$\mathrm{T}_{2}$ - Fermented malunggay
$\mathrm{T}_{3}$ - Fermented banana peel
$\mathrm{T}_{6}-\mathrm{T}_{1}+\mathrm{T}_{3}$ (1:1 ratio)
$\mathrm{T}_{4}$ - Fermented kuhol
$\mathrm{T}_{7}-\mathrm{T}_{1}+\mathrm{T}_{4}(1: 1$ ratio $)$
$\mathrm{T}_{8}-\mathrm{T}_{2}+\mathrm{T}_{3}+\mathrm{T}_{4}$ (1:1:1 ratio)

Table 4. Interaction effect on fruit size of ampalaya as influenced by different nutrient solutions and their combination under aggregate hydroponic system

\begin{tabular}{lcc}
\hline \multirow{2}{*}{ Treatment } & \multicolumn{2}{c}{ Length $(\mathbf{c m})$} \\
\cline { 2 - 3 } & Galaxy & Jade star \\
\hline $\mathrm{T}_{1}$ - Commercial nutrient solution & $25.66^{\mathrm{a}}$ & $24.72^{\mathrm{ab}}$ \\
$\mathrm{T}_{2}-$ Fermented malunggay & $20.95^{\mathrm{d}}$ & $20.91^{\mathrm{d}}$ \\
$\mathrm{T}_{3^{-}}$Fermented banana peel & $23.38^{\mathrm{bc}}$ & $21.01^{\mathrm{d}}$ \\
$\mathrm{T}_{4^{-}}$Fermented kuhol & $24.03^{\mathrm{abc}}$ & $20.90^{\mathrm{d}}$ \\
$\mathrm{T}_{5^{-}} \mathrm{T}_{1}+\mathrm{T}_{2}(1: 1$ ratio $)$ & $24.33^{\mathrm{abc}}$ & $24.17^{\mathrm{ab}}$ \\
$\mathrm{T}_{6}-\mathrm{T}_{1}+\mathrm{T}_{3}(1: 1$ ratio $)$ & $25.72^{\mathrm{a}}$ & $25.40^{\mathrm{a}}$ \\
$\mathrm{T}_{7^{-}} \mathrm{T}_{7^{-}} \mathrm{T}_{1}+\mathrm{T}_{4}(1: 1$ ratio $)$ & $25.66^{\mathrm{a}}$ & $23.23^{\mathrm{bc}}$ \\
$\mathrm{T}_{8^{-}} \mathrm{T}_{8}-\mathrm{T}_{2}+\mathrm{T}_{3}+\mathrm{T}_{4}(1: 1: 1$ ratio $)$ & $21.45^{\mathrm{d}}$ & $22.61^{\mathrm{abcd}}$ \\
$\mathrm{CV}(\%)=17.59$ & 3.92 & \\
\hline
\end{tabular}

Means within the same column without and with the same letter designation are not significantly different at $5 \%$ and $1 \%$ level, using Least Significant Difference (LSD)
Legend: $\mathrm{T}_{1}$-Commercial nutrient solution
$\mathrm{T}_{5}-\mathrm{T}_{1}+\mathrm{T}_{2}(1: 1$ ratio $)$
$\mathrm{T}_{2}$ - Fermented malunggay
$\mathrm{T}_{3}$ - Fermented banana peel
$\mathrm{T}_{4}$ - Fermented kuhol
$\mathrm{T}_{6}-\mathrm{T}_{1}+\mathrm{T}_{3}$ (1:1 ratio)
$\mathrm{T}_{7}-\mathrm{T}_{1}+\mathrm{T}_{4}$ (1:1 ratio)
$\mathrm{T}_{8}-\mathrm{T}_{2}+\mathrm{T}_{3}+\mathrm{T}_{4}(1: 1: 1$ ratio $)$




\section{Profitability Analysis}

Table 6 shows the estimates of the cost and return of ampalaya production as influenced by different nutrient solutions and their combination under aggregate hydroponic system in a 60 -meter by 5 -meter protective structure with the prevailing local price of Php 50 per kilogram. Except for the use of pure fermented banana peel as nutrient solution, the treatments showed positive return. However, the net income generated did not vary significantly between ampalaya varieties, namely: Galaxy and Jade Star. Among the different nutrient solutions, commercial inorganic solution significantly gave the highest net income regardless of the ampalaya variety used. This result is comparable to the net return generated from the combined use in equal proportions of (a) commercial nutrient solution and fermented malunggay $\left(T_{5}\right)$, (b) commercial nutrient solution and fermented banana peel $\left(T_{6}\right)$, and (c) commercial nutrient solution and fermented kuhol $\left(T_{7}\right)$. On the other hand, the ampalaya hybrids applied with organic ferments alone generated significantly lower net returns. The overall result, nonetheless, implies that ampalaya production using an aggregate hydroponic system is profitable.

Table 6. Cost and return analysis of ampalaya as influenced by different nutrient solutions and their combination under aggregate hydroponic system in a $60 \mathrm{~m}$ by $5 \mathrm{~m}$ area

\begin{tabular}{llrrrr}
\hline Variety & $\begin{array}{c}\text { Nutrient } \\
\text { Solutions }\end{array}$ & Yield $(\mathbf{k g})$ & $\begin{array}{r}\text { Gross } \\
\text { income }\end{array}$ & $\begin{array}{c}\text { Total } \\
\text { expenses }\end{array}$ & $\begin{array}{c}\text { Net income } \\
\text { (Php) }\end{array}$ \\
\hline \multirow{6}{*}{ Galaxy } & $\mathrm{T}_{1}$ & 788.24 & $39,412.00$ & $10,102.00$ & $29,310.00^{\mathrm{a}}$ \\
& $\mathrm{T}_{2}$ & 215.92 & $10,796.00$ & $9,302.00$ & $1,494.00^{\mathrm{b}}$ \\
& $\mathrm{T}_{3}$ & 153.68 & $9,220.80$ & $9,152.00$ & $68.80^{\mathrm{b}}$ \\
& $\mathrm{T}_{4}$ & 246.24 & $12,312.00$ & $9,302.00$ & $3,010.00^{\mathrm{b}}$ \\
& $\mathrm{T}_{5}$ & 631.52 & $31,576.00$ & $9,702.00$ & $21,874.00^{\mathrm{a}}$ \\
& $\mathrm{T}_{6}$ & 697.92 & $34,896.00$ & $9,652.00$ & $25,244.00^{\mathrm{a}}$ \\
& $\mathrm{T}_{7}$ & 698.24 & $34,912.00$ & $9,702.00$ & $25,210.00^{\mathrm{a}}$ \\
& $\mathrm{T}_{8}$ & 195.04 & $9,752.00$ & $9,227.00$ & $525.00^{\mathrm{b}}$ \\
\hline \multirow{6}{*}{ Jade star } & $\mathrm{T}_{1}$ & 729.84 & $36,492.00$ & $10,102.00$ & $26,390.00^{\mathrm{a}}$ \\
& $\mathrm{T}_{2}$ & 206.16 & $10,308.00$ & $9,302.00$ & $1,006.00^{\mathrm{b}}$ \\
& $\mathrm{T}_{3}$ & 155.54 & $9,332.16$ & $9,152.00$ & $180.16^{\mathrm{c}}$ \\
& $\mathrm{T}_{4}$ & 436.80 & $21,840.00$ & $9,302.00$ & $12,538.00^{\mathrm{b}}$ \\
& $\mathrm{T}_{5}$ & 630.96 & $31,548.00$ & $9,702.00$ & $21,846.00^{\mathrm{a}}$ \\
& $\mathrm{T}_{6}$ & 641.52 & $32,076.00$ & $9,652.00$ & $22,424.00^{\mathrm{a}}$ \\
& $\mathrm{T}_{7}$ & 661.60 & $33,080.00$ & $9,702.00$ & $23,378.00^{\mathrm{a}}$ \\
& $\mathrm{T}_{8}$ & 207.12 & $10,356.00$ & $9,227.00$ & $1,129.00^{\mathrm{b}}$ \\
\hline
\end{tabular}

Legend: $\mathrm{T}_{1}-$ Commercial nutrient solution

$\mathrm{T}_{2}$ - Fermented malunggay

$\mathrm{T}_{3}$ - Fermented banana peel

$\mathrm{T}_{4}$ - Fermented kuhol
$\mathrm{T}_{5}-\mathrm{T}_{1}+\mathrm{T}_{2}$ (1:1 ratio)

$\mathrm{T}_{6}-\mathrm{T}_{1}+\mathrm{T}_{3}$ (1:1 ratio)

$\mathrm{T}_{7}-\mathrm{T}_{1}+\mathrm{T}_{4}$ (1:1 ratio)

$T_{8}-T_{2}+T_{3}+T_{4}(1: 1: 1$ ratio $)$ 


\section{CONCLUSIONS}

The two ampalaya hybrids grown in aggregate hydroponic system responded well in terms of horticultural and yield parameters. The best performance was achieved using pure commercial inorganic solution followed by the combination of commercial solution with organic ferments. The poorest performing plants were those grown in pure banana peel ferments. The production of ampalaya under aggregate hydroponic system is profitable with the application of commercial inorganic solution or the combination of organic ferments and commercial inorganic nutrient solution.

The use of commercial solution or in combination with organic ferments is recommended because of its great potential in cost reduction and profitability. It is further suggested that the adoption of this technology be promoted among farmers for sustainable ampalaya production in the country.

\section{ACKNOWLEDGMENT}

The authors are thankful to the Visayas State University (VSU) and the Department of Science and Technology-Accelerated Science and Technology Human Resource Development Program-National Science Consortium (ASTHRDP-NSC) scholarship for the financial support extended to this research.

\section{REFERENCES}

Banez BP and Manipon FR. 2000. Crop production under greenhouse and soilless media culture (Los Baños conditions). Paper presented at the Workshop on the Packaging of Hydroponics R\&D Program for High Value Crop Production in the Philippines. PCARRD, Los Baños, Laguna. pp 1214

El-Shinawy MZ, Abd-Elmobiem EM \& Abou-Hadid AF. 1999. The use of organic manure for lettuce plants grown under NFT conditions. Acta Hort. 491:315-318

Gul A, Kidoglu F \& Anac D. 2007. Effect of nutrient sources on cucumber production in different substrates.Sci. Hort. 113:216-220

Kratky BA and Bowen JE. 1988. Observations on a Noncirculating Hydroponic System for Tomato Production. HortScience 23 (5): 906-907

Rao I and Cramer G. 2003. Plant nutrition and crop improvement in adverse soil conditions. In: M. Chrispeels and D. Sadava (eds). Plants, Genes, and 
Crop Biotechnology. Published in partnership with the American Society of Plant Biologists and ASPB Education Foundation. Jones and Bartlett Publishers, Sudbury, Massachusetts, USA.pp.270-303.

Salas FM and Salas RA. 2014. Liquid nutrient formulations for lettuce (Lactuca sativa L.) production under an aggregate hydroponics system. In Proceedings: $44^{\text {th }}$ Crop Science Society of the Philippines Scientific Conference held at Parklane International Hotel, Cebu City on March 1216,2014

Salas FM, Pole VN, Salas RA \& Quevedo MA. 2013. Shelf life and Free

Radical Scavenging Activity of Harvested Bitter Gourd (Momordica charantia L.) Coated with Phytochemical Extracts. In Proceedings: Second Southeast Asia International Conference on Quality Management in Postharvest Systems held at Lane Xang, Vientiane, Lao PDR on December 4-6, 2013

Succop CE. 1998. Soilless Culture, Proceedings of the IPI 1968 6th Colloquium of the International Potash Institute. Florence, Italy. Pp: 324341

Taiz L and Zieger E. 1998. Plant physiology. Sinauer Associates, Inc. Publishers. Sunderland, Massachusstes, U.S.A

Jensen M. 1991. Hydroponic Culture for the Tropics: Opportunities and Alternatives. Department of Plant Sciences University of Arizona, U.S.A Department of Agriculture. "Ampalaya Production Guide". 2017. https://ph.eastwestseed.com/ 